\title{
The Study of Java's Islamization Process in Serat Rengganis through Manuskrip Digitalization Program
}

\author{
S W el Firdausy ${ }^{1}$, M F H Kamalia ${ }^{2}$ \\ Faculty of Adab and Humanities (FAHUM) Universitas Islam Negeri Sunan Ampel Surabaya, \\ Indonesia ${ }^{1,2}$ \\ \{syarifahwardahef@gmail.com ${ }^{1}$,imakamalia@gmail.com $\left.{ }^{2}\right\}$
}

\begin{abstract}
This study aims to digitize the Serat Rengganis manuscript as well as to find out the relation between Serat Rengganis and the process of Javanese Islamization. The results of this study are the digitization program of Serat Rengganis manuscript as an effort to prevent Serat Rengganis from extinction. The digitalization of the manuscript is undertaken by taking pictures, editing them by using Microsoft Office Picture Manager and Corel Draw and saving them in the digital storage. Furthermore, it can be seen that Serat Rengganis contains the acculturation between Javanese Hindu literature and Islamic literature through the steps of philological research work. It can be seen by the presence of the main character, Dewi Rengganis, who had previously been known by the Javanese people in the Majapahit Kingdom. The figure of Dewi Rengganis was reappeared in Serat Rengganis as the main figure who converted as a Muslim. The process of Islamization of the Javanese community by reading Serat Rengganis was obtained through self-identification between the main character and the readers. It aims to make the readers, who have liked the figure of Dewi Rengganis in the Majapahit era, also able to convert to Islam as done by Dewi Rengganis. The Islamization of Javanese people through the Islamic literary work is the proof that Islam preached by Wali Songo in the $14^{\text {th }}$ century was done wisely without coercion and also enhanced the good values that had existed before.
\end{abstract}

Keywords: Digitalization of Manuscripts, Javanese Islamization, Serat Rengganis

\section{Introduction}

The Islamization of Java around the midst $14^{\text {th }}$ century until the $16^{\text {th }}$ century performed by Wali Songo through education with the old manuscripts ultimately resulted in various types of handwritten manuscripts. Among the results of the handwritten manuscript is an epic literary manuscript titled Serat Rengganis owned by K.T Poesponegoro I-the first Regent of Gresik-which becomes the focus of this study. Serat Rengganis is a manuscript written in Kartasura era under the palace poet, namelyRangga Janur. Serat Rengganis contains a continuation of Menak story - with The King of Amir Hamzah as the main character who fights against the pagan kingdom — but it added the figure of Dewi Rengganis as another main 
character in it. Dewi Rengganis is a phenomenal figure who has been known by the Javanese people in the Majapahit Kingdom era. Serat Renganis intends to educate them that their favorite character in Serat Rengganis had been already a Muslim [1]. He also played a role both as warlord against the pagan kingdoms of China and a son-in-law of the King of Amir Hamzah (uncle of the Prophet Muhammad). The writing of the Serat Rengganis refers to the process of Islamization of Java through a persuasive, deductive, and wise manner by writing epic literary manuscripts with the main characters favored by the Javanese people.

The literature review in this study is divided into three parts which are the main literature, supporting literature and complementary literature. The main literature of the study is Serat Rengganis manuscript using Javanese-language pegon script - a collection belonging to the family of K.T Poeponegoro as the first Regent of Gresik - which is stored in Prigen-PasuruanEast Java. Furthermore, supporting literature of the study refers to comparative literature as the proof that the story of Dewi Rengganis as the main character was known by the Javanese people in Majapahit Kingdom era. Among them are the books of (1) Rengganis written by Wacana [2], (2) Rengganiswritten by Wacana [3](3) Kitab Rengganis the compilation book of Kapustakaan Djawa pages 126-134 compiled (1952), and (4) Potensi Cerita Rakyat Dewi Rengganis sebagai Pendukung Upaya Pemerintah Mengatasi Personal Lingkungan Hidup [4].

This study uses some complementary literatures in order to determine the methods of preaching of Nusantara Islamization during the Wali Songo era, namely the books of (1) Sekitar Wali Songawritten by Salam [5], (2) The History of Javawritten by Raffles [6](3) Mengislamkan Tanah Jawa: Telaah atas Metode Dakwah Walisongo written by Saksono [7], (4) Islamisasi di Jawa: Wali Songo Penyebar Islam di Jawa menurut Penuturan Babadwritten by Sofwan et al [8] and (5)Atlas Wali Songowritten by Suyoto [9]

Furthermore, this study aims to (1) digitize Serat Rengganis manuscripts as the effort to save manuscripts from extinction and (2) Determine the relation between Serat Rengganis and the process of Islamization of Java through the method of the preaching of pegon-scripted manuscripts writing nuanced literary works in Islamic boarding schools.

\section{Method}

This study uses qualitative methods based on literature and field data. Literature data are used to analyze the relation between Serat Rengganis and the process of Islamization of Java through the method of the preaching of manuscript writing, while field data is needed in the process of digitizing Serat Rengganis manuscript which is stored in the community. The data are collected in various ways, such as object determination, data collection, and data analysis:

The object of this study is Serat Rengganismanuscript using Javanese-language pegon script $-\mathrm{a}$ collection belonging to the family of K.T Poeponegoro as the first Regent of Gresik - which is stored in Prigen-Pasuruan-East Java.

This study uses literature and field data collection methods. Literature data are divided into three types, namely the main literature; supporting literature; and supplementary literature as explained in the introduction. While the field data needed in order to assess Serat Rengganis manuscripts stored in the community and digitize the manuscript through several stages (b.1) shooting, (b.2) Editing using Microsoft Office Picture Manager and Corel Draw, and (b. 3) Digital storage.

Analysis of the data used in this study includes analysis of philological theory, text interpretation, and descriptive analysis. Analysis of philological theory is used to get the translation of Serat Rengganis in Indonesian. The steps of philological research work are 
divided into several stages, namely: (c.1) Determination and understanding of objects; (c.2) Inventory of manuscripts and catalog studies; (c.3) Codicology/description of the manuscript; (c.4) The first stages of textology include transliteration and editing of the text; (c.5) The second stage of textology involves translating text in Indonesian [10].

It is also necessary to interpret the text to find out the contents or the facts of Serat Rengganis manuscript [11]. Therefore, this study uses the Javanese Islamization approach in the Wali Songo era in order to determine the relation between Serat Rengganisand the method of Islamization of Java in the $14^{\text {th }}$ century through the method of preaching of pegon manuscript writing.

Furthermore, the descriptive analysis in this study is used through systematic exposure to obtain a clear depiction of what is intended. In addition, the analysis will be done by comparing the data with others, seek linkages with one another, and evaluate each other [12] so that the findings in this study are expected to be placed in the perspective of new scientific treasures and discoveries.

\section{Result and Discussion}

\section{Adaptation of Handwritten Cultural in Hindu-Buddhist Era during Nusantara Islamization}

Among the local cultures that were adapted and used in Wali Songo preaching was the education of Islamic manuscripts writing. It was widely known that the Nusantara people had known handwritten culture by using local paper medium made from palm leaves, deluwang, and delancang since the Srivijaya kingdom era under the dynasty of Syailendra.

The era of Hindu-Buddhist kingdoms in the archipelago was marked by the emergence of the kingdom of Kutai (East Kalimantan) in the $4^{\text {th }}$ century and Tarumanegara (West Java) in the $5^{\text {th }}$ century [13]. In the Kutai kingdom era, the people of the archipelago were already familiar with writing. However, it was still used stone and monument media in its writing. One of the earliest evidence of writing using stone was found in the relics of the Kingdom of Kutai, known as the inscription. The inscription is called Yupa in which written the history of the Kutai kings [13].

Furthermore, there was a large kingdom in Palembang in the $7^{\text {th }}$ century known as the Kingdom of Srivijaya who reigned for six centuries. The Srivijaya kingdom was originally a Hindu kingdom under the Sanjaya dynasty, but it changed into a Buddhist kingdom under the dynasty of Syailendra [13]. The dynasty of Syailendra was known as the dynasty that succeeded in developing art, language, culture, and knowledge [14].

Then, the initial milestone of writing manuscripts in the archipelago using palm leaves began under the dynasty of Syailendra who ruled during the Ancient Mataram Kingdom by considering that the printed paper in the archipelago was only known in the $19^{\text {th }}$ century during the Dutch colonial era. Therefore, Nusantara people began to write using handwriting on paper made from palm leaves in the early days of civilization after using the stone and pillar media.

The earliest manuscript produced during the Ancient Mataram period was titled Kitab Chanda Karana. It was not certainly stated the time of writing and the name of the author. However, the writing of Kitab Chanda Karana was under the dynasty of Syailendra during the leadership of the $9^{\text {th }}$ Ancient Mataram king named Maharaja Dyah Balitung/King of Balitung (enthroned in 898-910 AD). In other words, it can be said that the writing of Kitab Chanda Karana which was around 898-910 AD was related to the leadership of King of Balitung. 
Kitab Chanda Karana contains moral teachings, song art (Javanese poetry), and lexicography or dictionary compilation[15].

After that, Majapahit Kingdom had collapsed between the end of the $14^{\text {th }}$ century and the beginning of the $15^{\text {th }}$ century when Islam began to be accepted in the Archipelago. The archipelago, which had previously been familiar with the tradition of writing manuscripts during the period of the Hindu-Buddhist kingdom, could wholly accept Islam since Islam also used the writing manuscript tradition as part of the mission of Islamization through education.

The use of scripts in writing manuscripts that previously used the Sanskrit Palawa script switched to use Old Javanese script and language and then followed to use the Carakan script (hanacaraka) in Javanese. So, when Islam entered the Malay Archipelago, the Jawi script (the Arabic language of Malay language) became widely known. Furthermore, when Islam entered Java, it began to be known and taught the pegon script (Javanese Arabic, Madurese, and Sundanese). Jawi script was taught in Islamic boarding schools in the Malay region which was formerly known as surau while Pegon script was taught in Islamic boarding schools in Java and Madura using the yellow book (Kitab Kuning). The Pegon script was partly written with vowel (kharokat), and partly written without vowel or kharokat(pegon gundhil).

The Hindu-Buddhist scientific tradition in the archipelago through the handwritten manuscript writing continued and developed during the Islamization of the archipelago. The delivery of the values and teachings of Islam towards the people in the archipelago is through writing manuscripts with jawi script, carakan script, and pegon script.

The saints adopted this tradition in preaching Islam in the archipelago. It point outs that Islam was preached in a peaceful manner, without coercion with the good values that had existed before. In fact, these virtues were perfected when Islam entered the archipelago, especially through manuscript writing.

\section{The Results of Serat Rengganis Manuscript Digitalization}

Saving the manuscript through the process of digitizing the manuscript in this study is done through the stages of the description of the manuscript. Furthermore, Hermansoemantri (1986) explains some requirements that need to be considered in describing the manuscript, including: (1) the title of the manuscript, (2) the number of the manuscript, (3) the place of storage of the manuscript, (4) the origin of the manuscript, (5) the condition of the manuscript, (6) the size of manuscript, (7) the thickness manuscript, (8) number of lines per page, (9) Letters, (10) Ways of writing, (11) the material of manuscript, (12) the language of manuscript, (13) the form of manuscripts, (14) the age of manuscripts, (15) Author / Copter, (16) the origins of manuscripts, (17) the social functions of manuscripts, and (18) Overview of texts or stories.

\section{The Title of Manuscript}

\section{a. The Explicit Title of the Manuscript}

There is an explicit title in this text. The title can be read directly because the owner of the manuscript, in this case, is a large family, of K.T (Ki Tumenggung) Poesponegoro-First Regent of Gresik who collected this manuscript in The Poesponegoro Community has given the title to the manuscript by slipping a small piece of white paper, neat and laminated inside the manuscript. The paper is written as follows: 


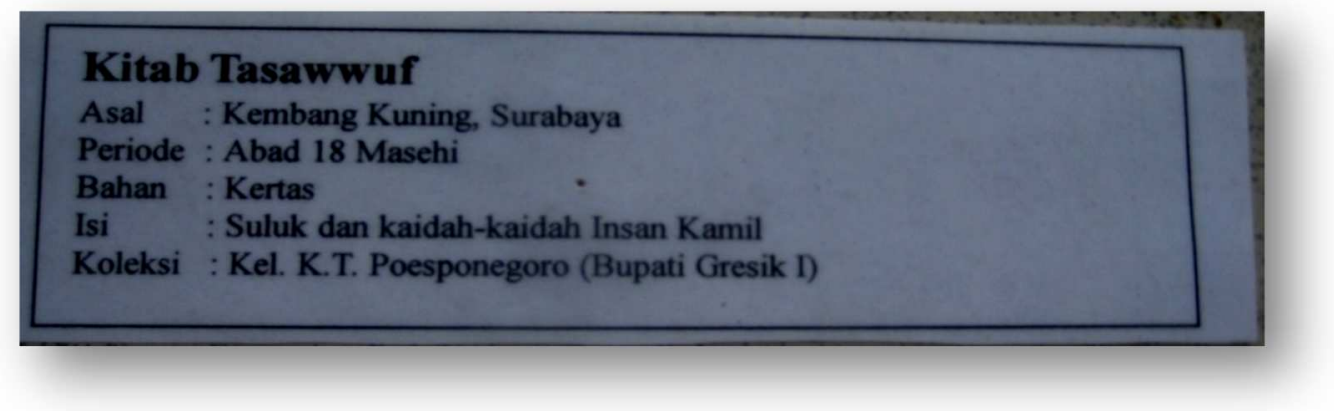

Fig. 1. Explicit Title of Manuscript

Based on the picture above, it can be seen that the manuscript has the title of KitabTasawwuf which contains Suluk and the rules of Insan Kamil. The title of is based on a separate reason chosen by the collector or the owner of the manuscript. However, after further reading, compatibility is not found in the study of tasawwuf from this text. It was presumably considered as the study of suluk because the writer gave the word of "culuk", especially in the opening speech, in the beginning of asmaradhana section.

\section{b. Hermenuitic Readings on the Title of the Manuscript}

After repeated readings, many writings of the names of Amir Hamzah are found in this manuscript. The name of Amir Hamzah is mentioned repeatedly by writing the name of Maha Raja Amir Hamzah. It also happened to the name of Amir Ambyah; The Nata; Jayeng Rana; Hamzah Kuwari, and Raden Hamzah. It can be seen in the picture of the script below:

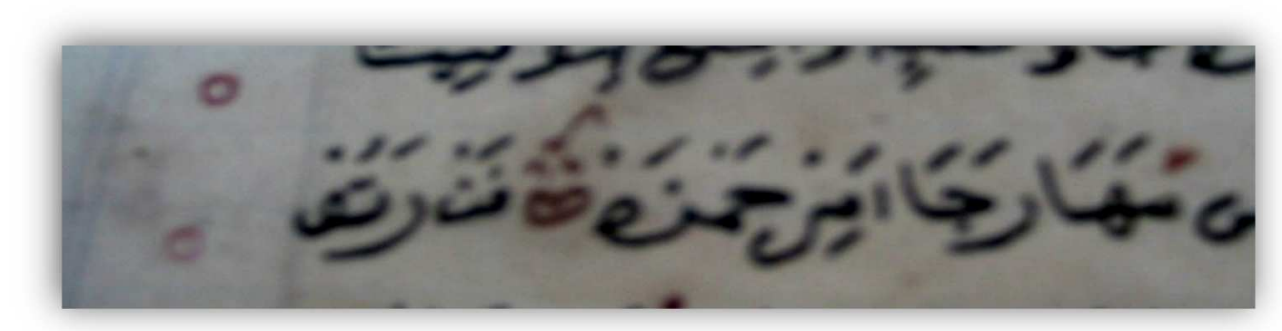

Fig. 2. The Writings in the Manuscript of Maha Raja Amir Hamzah

The name of Amir Hamzah that is often found in this manuscript eventually leads to the hypothesis that this manuscript is a variant of the Amir Hamzah Hikayat manuscripts known by the Malay community. However, the variant of the Amik Hamzah Hikayat manuscript in Javanese society is known as Serat Menak.

Not only the name of Amir Hamzah figure but also the name of Dewi Rengganis are repeatedly mentioned. The mention of the name of Dewi Rengganis in this manuscript exceeds the number of Amir Hamzah's name. Therefore, Dewi Rengganis is thought to have a role as the main character in this manuscript. The writing of her name can be seen through the picture below: 


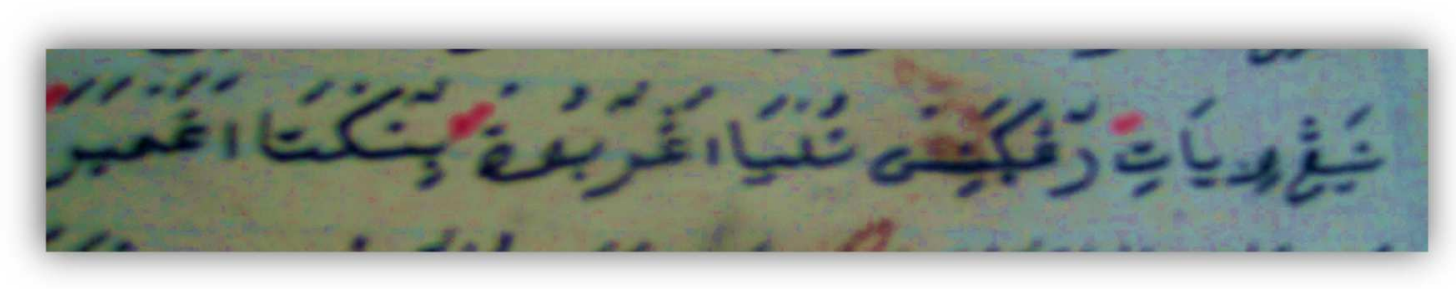

Fig. 3. The Writing of the Manuscript: Neng Wiyati Rengganis Nulya Angrěbut Biněkta Angarab

After the reading of the books of (1) Katalog Induk Naskah-Naskah Nusantara Jilid I Koleksi Museum Sonobudoyo Yogyakarta [16], (2) Katalog Induk Naskah-naskah Nusantara Jilid 3-A Fakultas Sastra Universitas Indonesia [17], and (3) Direktori Edisi NaskahNusantara [18], it is found the title of Menak Rengganis manuscript and Serat Rengganis manuscript. In subsequent readings, it is known that there is no script with the title of Menak Rengganis in the Menak story script series. Besides, the writing of the manuscript in Javanese pegon script in this manuscript indicates that this manuscript can be suitably referred to a manuscript with the type of serat derived from the Arabic surah.

Based on the reading process, this manuscript is finally entitled to Serat Rengganis because of the compatibility of the contents with Serat Rengganis variant that has been collected in the Literature Edition Directory of the Archipelago literature and the four Nusantara manuscript catalogs that mentioned above.

\section{The Condition of the Manuscript}

The condition of the color of Serat Rengganis's paper has turned into yellow, although it is still quite good. In addition, Serat Rengganis's paper also has an uneven brownish color and uneven edges of the paper. It can be seen in Figure 4:

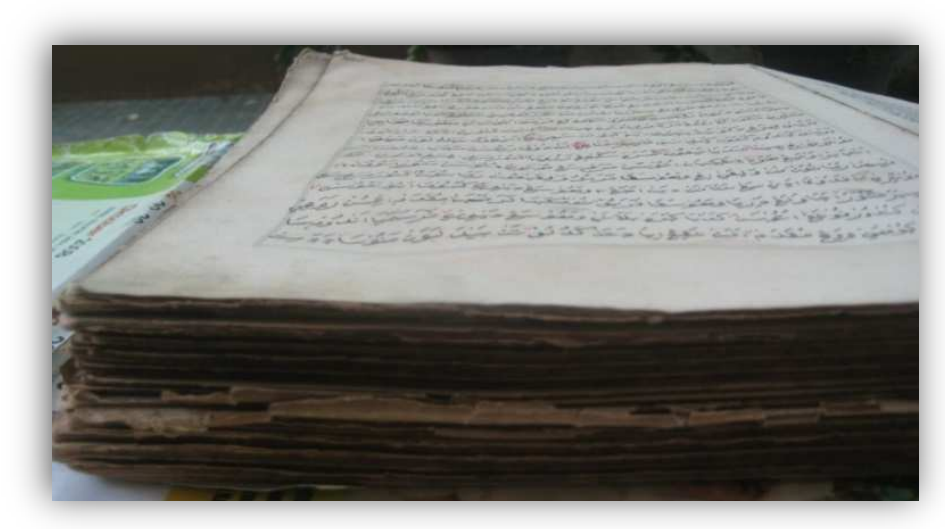

Fig. 4. Uneven Edges of the Paper

Some papers look loose from its binding, but the writing remains legible. This can be seen in the Figure 5: 


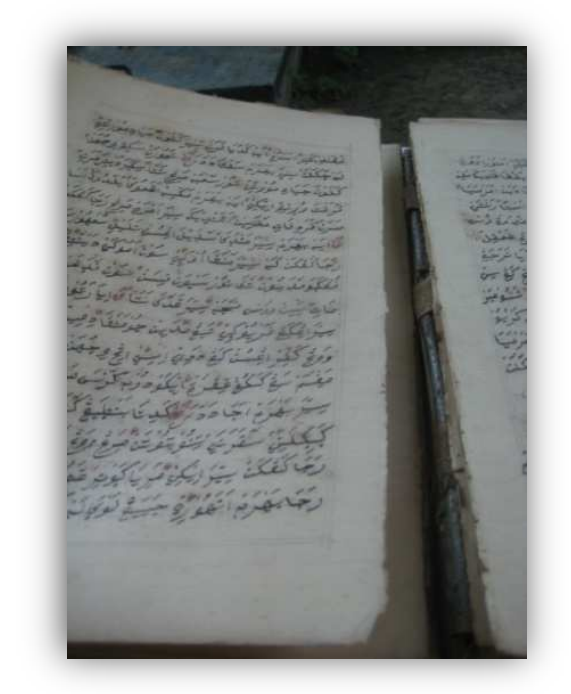

Fig. 5. The Paper Condition that Loose from its Binding

The color of Serat Rengganis cover is red and it was made of cardboard printed paper. The red color on the cover is not bright and there are some white patches on it. The edges are given black tape that functions to keep the papers from being separated from one another. The red cover on the front and back of the manuscript is an attempt to save the manuscript since its condition has already been in a quite bad condition. It can be seen in Figure 6:

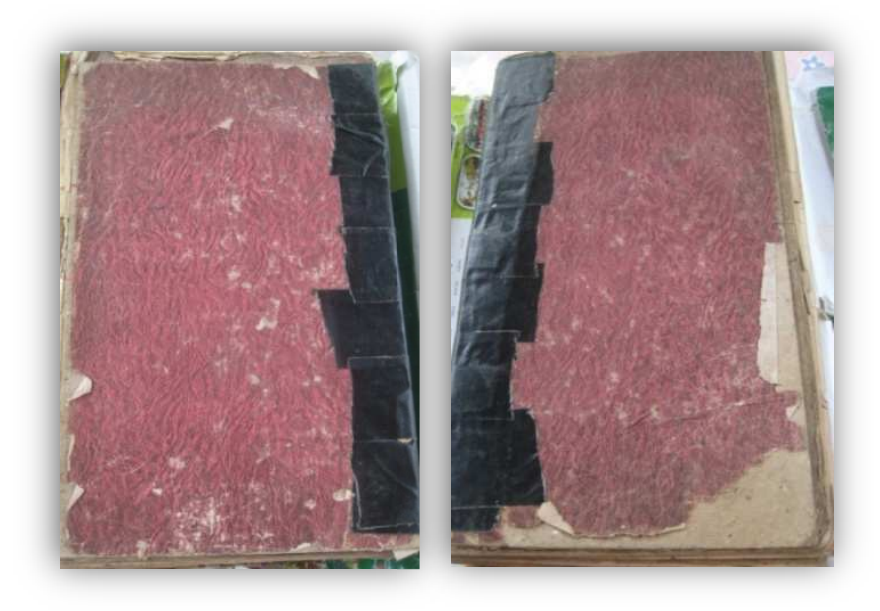

Fig. 6. The Front and the Back Cover of Serat Rengganis

Furthermore, the thickness of Serat Rengganis contains forty-eight (48)sheets of front and back (recto-verso). Therefore, it can be seen that the total number of pages of Serat Rengganis scripts is ninety-six(96) pages. It can be seen in Figure 7: 


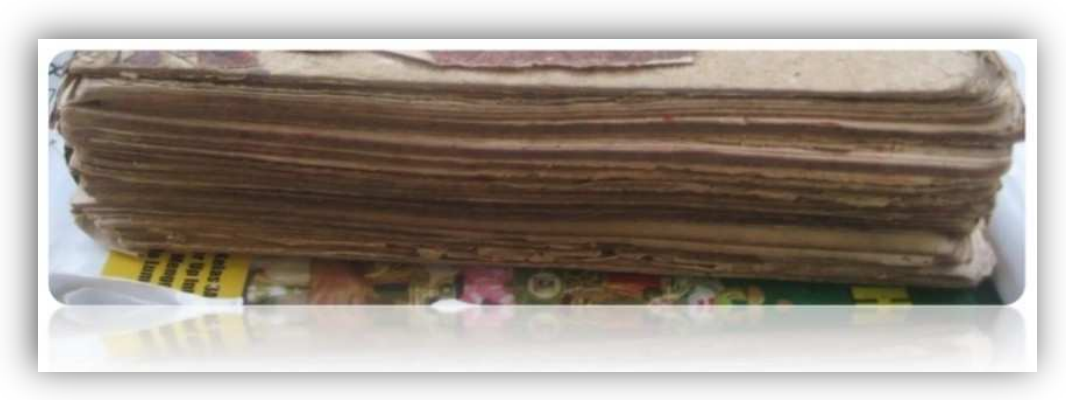

Fig.7. The Thickness of Serat Rengganis Manuscript

There are twenty-two (22) bundles of white thread in Serat Renggganis. Each tie serves to bind the paper to one another so that it will not separate from its binding. It can be seen in Figure 8:

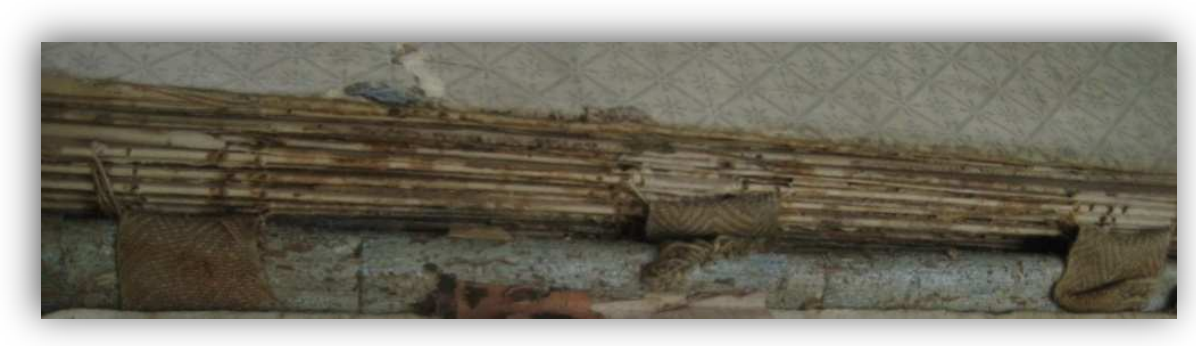

Fig. 8. Twenty-two (22) White Thread Binding of Serat Rengganis

The number of lines in Serat Rengganis is divided into two parts. The first part is the opening (initial part) of Serat Rengganis that contains nine (9) lines, while in the content part contains sixteen (16) lines on each page. It can be seen in the image below:
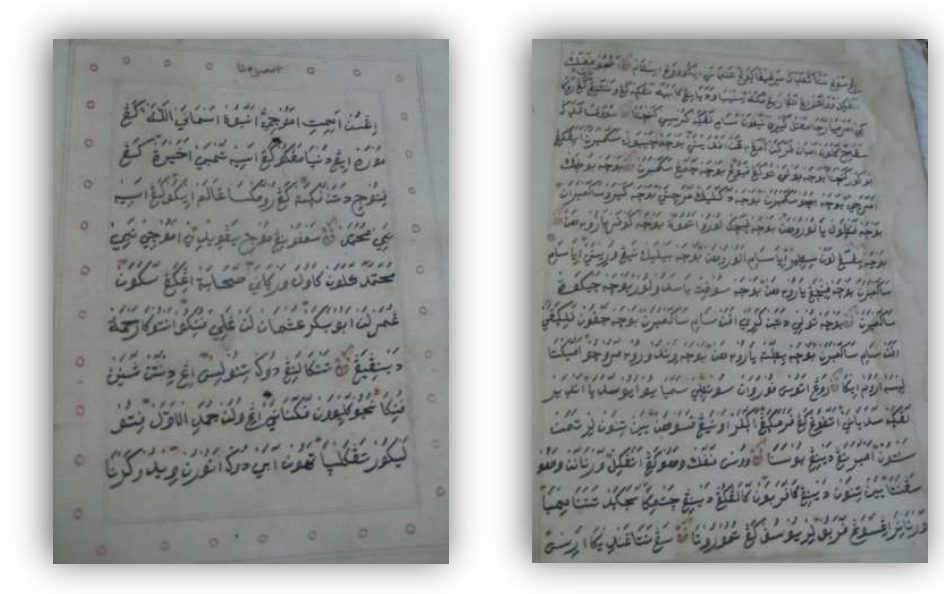

Fig. 9. Each Page Contains 9-18 Lines in Serat Rengganis 
Next, there are several ink colors used in Serat Rengganis. Black ink is used in the contents of the story, red ink is used as a marker of the change in the contents of the story, and blue ink is used in the beginning of story to introduce the identity of the author of Serat Rengganis. It can be seen in Figure 10:

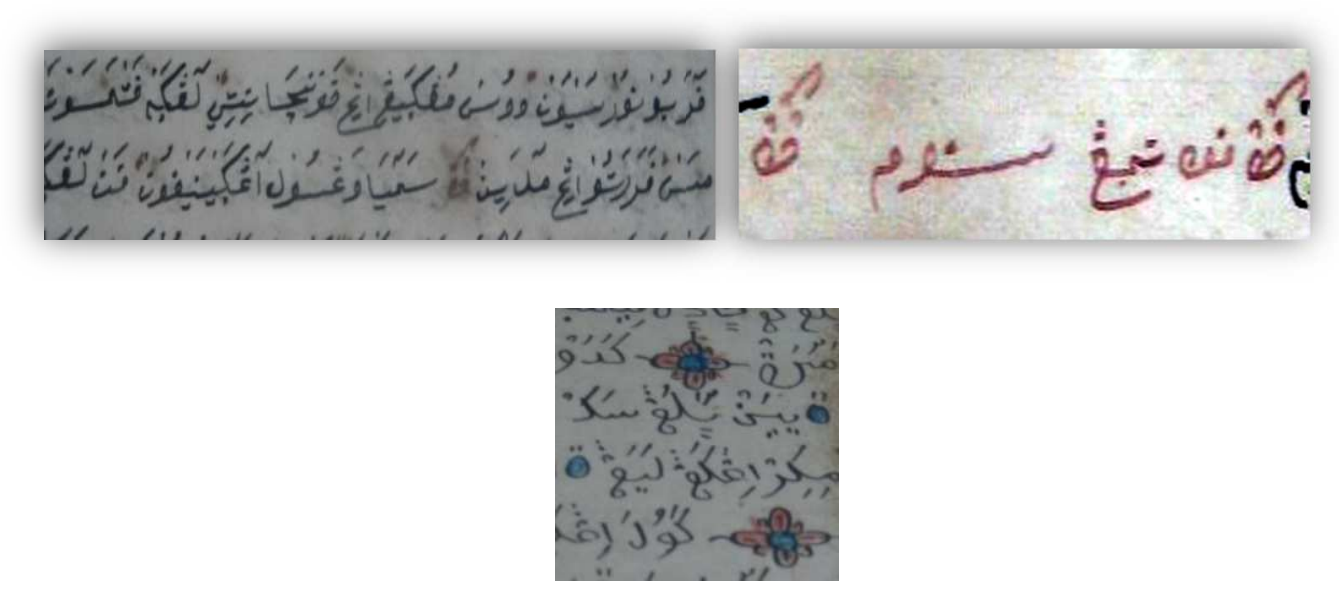

Fig. 10. Black, Blue, and Red Ink Colors Used in Serat Rengganis

The Linkage of between Serat Rengganis and the Process of Islamization of Java through the Writing of Literary-Patterned Manuscripts

Serat Rengganis was first written by a poet named Rangga Janur in the Kartasura era. This information was obtained from the book of Research of Language and Literature in Coastal Demak [19]. It is stated that:

\section{"Lelewaning basa Serat Rengganis taksih celak sangat kaliyan serat Menak Kartasura kasebat ing nginggil (gaya bahasa Serat Rengganis itu masih sangat dekat dengan Serat Menak Kartasura)."}

Serat Rengganis is the heroic text (epic literature) with Dewi Rengganis and Amir Hamzah as the main characters. Dewi Rengganis in Serat Rengganis, is Amir Hamzah's daughter-in-law who married his son, named Raden Imam Suwangsa. During the Majapahit Kingdom, it was known that the figure of Dewi Rengganis had been known by the Javanese people. Dewi Rengganis folklore is known by the people around Argopuro Mountain, Probolinggo-East Java. Dewi Rengganis was known as a beautiful princess who lived on Argopuro Mountain. She was a magic human considering that she was a mixed creature between the jinn and the human who was told to eat flowers around Mount Argopuro. Because of the developing folklore, the people around Argopuro Mountain started to believe the folklore of Dewi Rengganis. As a result, the flower gardens around Argopuro Mountain were preserved and not freely picked by people considering that it was a residence of Dewi Rengganis [4].

Dewi Rengganis was known in the Hindu-Buddhist era and she was reappeared during the Islamization of Java in Serat Rengganis as Amir Hamzah's daughter-in-law. Dewi 
Rengganis was told as a Muslim and became a war leader of the Arab army under the leadership of the King of Amir Hamzah. Amir Hamzah himself was the uncle of Rasulullah SAW who was known to be tough and unbeatable. The story of Amir Hamzah in the Persian literature was recorded in the Qise'i Amir Hamzah manuscript. The stories with Amir Hamzah's figure were recorded in the Hikayat Amir Hamzah's manuscript during Islamization in Malay. Later, when Islam entered Java, Amir Hamzah's story was introduced to the Javanese community and converted into a 32-volume manuscript titled Serat Menak. Serat Menak contains the story of the King Amir Hamzah when he fought the kufr kingdoms with various names and storylines. At the end of the story, it was always told that the King of Amir Hamzah and his army won against the kufr kingdom [20].

Serat Rengganis was not included in the variant series story of Serat Menak. However, the characters in both Serat Rengganis and Serat Menak are the same which is using the main character of Amir Hamzah and the Arab army as his army. The difference between SeratMenak and Serat Rengganis is the addition of Dewi Rengganis in the story of Amir Hamzah's war against the kufr kingdom.

Serat Rengganis told the story of the war between the army of the Arab Empire led by King of Amir Hamzah and the Royal King of China led by a Chinese princess namely Dewi Wida Ningrum. Dewi Rengganis - who had been Muslim in Serat Rengganisplayed the role of the warlord of the Arab forces led by King of Amir Hamzah. Dewi Rengganis fought against the warlord of the Kingdom of China named Dewi Wida Ningrum. As told in the script, Dewi Wida Ningrum suffered defeat when fighting against Dewi Rengganis. She was hit by the arrow of Dewi Rengganis which was stuck in the chest of Dewi Wida Ningrum. After the defeat of the Chinese troops, it was said that the Chinese troops no longer dared to fight against the Arab forces anymore under the leadership of King of Amir Hamzah and his warlord, Dewi Rengganis.

\section{Self-Identification of Javanese People's on Dewi Rengganis}

Dewi Rengganis who had been known and idolized by the Javanese people in the Hindu-Buddhist era of the Majapahit Kingdom is a Muslim in Serat Rengganis. Therefore, Javanese people who had idolized Dewi Rengganis could follow the decision of Dewi Rengganis by writing a figure known by the Javanese community in the Islamic manuscript. This process is known as self-identification which is equating himself or herself with the idolized figure.

The existence of Serat Rengganis in the Archipelago could also be Aaphenomenal because it was widely copied in various regional languages in the Archipelago [4]. It indicates the mission of Islamization through literary works were successfully carried out by preachers and poets of ancient times.

The process of Islamization of the archipelago, especially in Javanese society, is undertaken through education by using the media of writing manuscripts containing teachings, values, and Islamic stories. This method points out that Islam preached by Wali Songo is peaceful and promotes compassion in every field.

Islamization through the writing of manuscripts that were previously known during the Hindu-Buddhist kingdom of Ancient Mataram reappeared during the Islamization of the archipelago, especially in Nusa Java. This was part of the process of strengthening the elements of the original culture of the archipelago through the principle of da'wah which later by the scholars was called al-muhafazah 'alal qadimish shalih wal akhdu bil jadili 
ashlah namely preserving the good treasures that had been existed before and adopting them in the latest of better developments[9]. The elements of local culture that already existed and were known before Islam entered the archipelago (in this case the tradition of writing manuscripts in Hindu-Buddhist times) through this principle of preaching. They are continuously refined with values as the mission of the Islamization of Java.

\section{Conclusion}

Digitization of Serat Rengganis manuscript is the attempt to save the contents of the manuscript from extinction by using some techniques, such as taking pictures, editing them by using Microsoft Office Picture Manager and Corel Draw and saving them in the digital storage. The result of digitizing Serat Rengganis manuscripts isa documentation of (1) the title of the manuscript, (2) the condition of the color of the paper, (3) the condition of the sheet of paper, (4) the condition of the cover of the manuscript, (5) the thickness of the manuscript, (6) the binding of the manuscript, (7) the number of lines per page in the manuscript, and (8) the ink colors.

Furthermore, the existence of Serat Rengganis manuscript is related to the process of Islamization of Java because Serat Rengganis was written in Old Javanese pegon script. Pegon script was known to be taught at the Islamization of Java era through learning in Islamic boarding schools. Furthermore, Dewi Rengganis, as the main figure in Serat Rengganis, had become the Muslim with aim of attracting the readers (the selfidentification process) of the manuscript to follow the decision of Dewi Rengganis to become the Muslim.

Furthermore, the study and digitalization of Islamization Javanese manuscripts are expected to be not limited only on literary manuscripts, but alsoon other scientific manuscripts, such as the book of fiqh, tasawwuf, philosophy, history, culture, laws, astronomy, medicine, and primbons which were also used in the mission of Islamization of Java at that time.

\section{References}

[1] Braginsky, "Sejarah Sastra Melayu dalam Abad 7-19," in Yang Indah, Berfaedah, dan Kamal, Jakarta: INIS, 1998.

[2] L. Wacana, Rengganis. Mataram: Proyek Rehabilitasi dan Perluasan Museum Tenggara Barat, 1977.

[3] Wacana, Rengganis. Jakarta: Proyek Penerbitan Buku Bacaan Sastra Indonesia dan Daerah, 1979.

[4] Y. and N. S. Sungkowati, Potensi Cerita Rakyat Dewi Rengganis sebagai Pendukung Upaya Pemerintah Mengatasi Personal Lingkungan Hidup. Surabaya: Balai Bahasa, 2008.

[5] S. Salam, Sekitar Wali Sanga. Kudus: Menara Kudus, 1960.

[6] Raffles Thomas Stamford, The History of Java (terj). London: Oxford University Pres, 1965.

[7] W. Saksono, Mengislamkan Tanah Jawa (Telaah atas Metode Dakwah Walisongo). Bandung: Mizan, 1995.

[8] E. a. Sofwan, Ridin, Islamisasi di Jawa: Wali Songo Penyebar Islam di Jawa menurut Penuturan Babad. Yogyakarta: Pustaka Pelajar, 2004.

[9] A. Sunyoto, Atlas Wali Songo (Buku Pertama yang Mengungkap Wali Songo sebagai 
Fakta Sejarah). Depok: Pustaka Iman, 2012.

[10] Robson, Principles of Indonesian Philology (terj). Leiden University: Foris Publication., 1988.

[11] A. and A. C. Z. Bakker, Metode Penelitian Filsafat. Yogyakarta: Pustaka Filsafat, 1994.

[12] F. Sanapiah, Penelitian Kualitatif Dasar-Dasar dan Aplikasi. Malang: Yayasan Asih Asah Asuh Malang, 1990.

[13] P. Setijo, Pendidikan Pancasila (Perspektif Sejarah Perjuangan Bangsa). Jakarta: Penerbit PT Grasindo, 2006.

[14] Zoetmulder, Kalangwan: Sastra Jawa Kuno Selayang Pandang. Jakarta: Penerbit Djembatan, 1983.

[15] Poerbatjaraka and Tarjan Hadidjaja, Kepustakaan Djawa. Djakarta-Amsterdam: Penerbit Djambatan, 1952.

[16] Behren, Katalog Induk Naskah-Naskah Nusantara Jilid I Koleksi Museum Sonobudoyo Yogyakarta. Jakarta: Djambatan, 1990.

[17] Behren \&Titik Pujiastuti, Katalog Induk Naskah-naskah Nusantara Jilid 3-A Fakultas Sastra Universitas Indonesia. Jakarta: Yayasan Obor Indonesia dan Ecole Francaise D’Extreme Orient, 1997.

[18] Masyarakat Pernaskahan Nusantara, Direktori Edisi Naskah Nusantara. Yayasan Pustaka Obor Indonesia, 1990.

[19] Poerbatjaraka, Bahasa dan Sastra Demak Pesisiran. Jakarta: Departemen Pendidikan dan Kebudayaan, 1984.

[20] Wijanarko, Selayang Pandang Wayang Menak. Solo: Amigo, 1991. 